\title{
Article \\ Effective and Promising Strategy in Management of Tomato Root-Knot Nematodes by Trichoderma harzianum and Arbuscular Mycorrhizae
}

\author{
Nivien A. Nafady ${ }^{1}$, Raoof Sultan ${ }^{1}$, Aida M. El-Zawahry ${ }^{2}$, Yasser S. Mostafa ${ }^{3}$, Saad Alamri ${ }^{3}$, Radwa G. Mostafa ${ }^{2}$, \\ Mohamed Hashem ${ }^{3, *(D)}$ and Elhagag A. Hassan $1, *$ (D) \\ 1 Botany and Microbiology Department, Faculty of Science, Assiut University, Assiut 71516, Egypt; \\ niviennafady@gmail.com (N.A.N.); raoofsultan06@gmail.com (R.S.) \\ 2 Plant Pathology Department, Faculty of Agriculture, Assiut University, Assiut 71526, Egypt; \\ elzawahry@aun.edu.eg (A.M.E.-Z.); radwa.ahmed@agr.aun.edu.eg (R.G.M.) \\ 3 Biology Department, Faculty of Science, King Khalid University, Abha 61413, Saudi Arabia; \\ Ysmosutafa@kku.edu.sa (Y.S.M.); saralomari@kku.edu.sa (S.A.) \\ * Correspondence: mhashem@kku.edu.sa (M.H.); elhagaghassan@aun.edu.eg (E.A.H.); \\ Tel.: +966-17-241-7625 (M.H.); Fax: +966-17-241-8202 (M.H.)
}

Citation: Nafady, N.A.; Sultan, R.; El-Zawahry, A.M.; Mostafa, Y.S.; Alamri, S.; Mostafa, R.G.; Hashem, M.; Hassan, E.A. Effective and Promising Strategy in Management of Tomato Root-Knot Nematodes by Trichoderma harzianum and

Arbuscular Mycorrhizae. Agronomy 2022, 12, 315. https://doi.org/ 10.3390/agronomy12020315

Academic Editors: Jaime Carrasco and Francisco J. Gea

Received: 28 December 2021

Accepted: 24 January 2022

Published: 26 January 2022

Publisher's Note: MDPI stays neutral with regard to jurisdictional claims in published maps and institutional affiliations.

Copyright: (C) 2022 by the authors. Licensee MDPI, Basel, Switzerland. This article is an open access article distributed under the terms and conditions of the Creative Commons Attribution (CC BY) license (https:// creativecommons.org/licenses/by/ $4.0 /)$.

\begin{abstract}
The ecosystem is considerably affected due to the extensive use of chemical pesticides and fertilizers. As an alternative strategy, this study aimed to assess the biocontrol potential of the bioagents arbuscular mycorrhizal fungi and plant growth-promoting Trichoderma harzianum MZ025966 against tomato root-knot nematodes (Meloidogyne javanica). T. harzianum showed a great potentiality to produce indole acetic acid (IAA) $(12.11 \pm 2.12 \mu \mathrm{g} / \mathrm{mL})$ and exhibited a noticeable activity of ammonification. Furthermore, T. harzianum revealed protease and lipase enzymatic activity of $28.36 \pm 2.82 \mathrm{U} / \mathrm{mL}$ and $12.30 \pm 0.31 \mathrm{U} / \mathrm{mL}$, respectively, which may illustrate the control mechanism of nematode eggs and juveniles. As in mycorrhizal and/or T. harzianum inoculated tomato plants, the penetration rates of nematodes, as well as the number of juveniles, females, egg mass, and galls were significantly reduced. The lowest number of juveniles was observed in the case of either single mycorrhizal inoculation (45\%) or in combination with T. harzianum (55\%). The enzymatic activity of glutathione peroxidase and catalase was enhanced in tomato plants inoculated with the bioagents to overcome the negative impact of nematode parasitism. Our results proved that the application of biocontrol agents not only reduced the nematode population and penetration rate but also improved the plant growth, increased the nutritional elemental content and stimulated the plant's systematic resistance.
\end{abstract}

Keywords: biocontrol agent; plant systematic resistance; arbuscular mycorrhizal fungi; Trichoderma harzianum; Meloidogyne javanica

\section{Introduction}

Nematodes, or roundworms, the most abundant animals in the world, constitute the phylum Nematoda. Nematodes occur as parasites in plants, animals, or as free-living forms in different habitats (marine environment, freshwater, and soils). Root-knot nematodes (genus Meloidogyne) (RKN) are endoparasites of roots and have been assessed to cause around USD 173 billion of annual damages to crops planted worldwide [1]. Nematode larvae infect the plant root system and develop root-knot galls that exhaust the plant's nutrients and photosynthate. Plant yields are reduced by nematode infection, while infection may be lethal in young plants [2]. Furthermore, nematodes are likely to be undervalued, because farmers are often oblivious of their presence because the plant symptoms caused by nematode infection are oftentimes non-specific, so it is difficult to attribute losses in crop to nematode infection [3]. Meanwhile, further losses might be correlated to the quality of 
food and morphological imperfections associated with nematode infection symptoms [4]. Nowadays, there is an increasing requirement for agricultural products from the growing population [5], and this can be met by optimizing the productivity potential and by controlling the crop losses caused by the plant-parasitic nematode [6]. Chemical nematicides are used to control nematode infection in agriculture, but they have adverse and toxic effects on human health, bioflora, animals, and are constituted of contaminants for the environment [7]. Hence, the need to use an effective and ecofriendly strategy for nematode management is increased and intensified with the reduction of the use of pesticides due to EU regulations (EC No1107/2009).

Nematode biological control occurs by reducing nematode infection and/or regulation of its populations through the activity of organisms that are antagonistic to them [8]. These organisms can interact with nematodes directly through antibiosis and competition for space or nutrients or interact indirectly with plant pathogenic nematodes by inducing resistance in the host plant $[8,9]$. Plant-growth-promoting fungi (PGPF) can act as efficient and ecofriendly nematode biocontrol, as well as biofertilizers for plant growth and yield improvement. It was reported that Trichoderma and mycorrhizal fungi are the most significant PGPF that were studied and used as bioagents against root-knot nematode as resistance inducers [8].

Arbuscular mycorrhizal fungi (AMF) are obligate root symbionts of, primarily, vascular plants. AMF are mainly used as biofertilizers, which can form symbiotic interactions with $90 \%$ of crop plants [10]. The biocontrol impact of mycorrhizal fungi has been observed against a wide range of phytopathogenic microorganisms [11,12]. Nematode infection decreased in mycorrhizal plants, and it is not clear if the reason for this reduction was due to systematic plant resistance or a direct effect [8], but the direct mechanisms used by AMF against nematode population or infection are not yet distinguished as they act only through the host plant (an indirect mechanism). Mycorrhizal fungi improve plant resistance through many activities such as the increase in plant nutrient uptake, the alteration in root morphology and structure, and the alteration of the rhizosphere interaction that makes the host plants more competitive for space and nutrients than other plants [13]. Moreover, mycorrhizal fungi induce systematic resistance (ISR) in plants against infection by pathogens and/or pests [14,15]. Mycorrhizal fungi stimulate the production of antioxidant enzymes, accumulation of non-enzymatic compounds inside cells of host plants, reduction in malondialdehyde production, the activation of enzyme-encoded genes involved in the biosynthesis of lignin, and in the shikimate pathway which produces forebears of different aromatic secondary metabolites against nematodes [16-19].

Trichoderma species were recognized as widely applicable microorganisms in agricultural technology as a biological control agent for many plant pathogens that inhabit plant-soil ecosystems. Furthermore, Trichoderma showed many unique properties including the ability to colonize plant roots [20], being easily culturable and propagated, improving plant growth and disease resistance [21], and improving nutrient utilization efficacy [22] and, consequently, improving its efficiency and applicability in agriculture and sustainable cropping systems. Interestingly, Trichoderma spp. were investigated by many authors for their potentiality in controlling plant pathogenic nematodes [23]; however, there is little information concerning the mechanisms of Trichoderma-nematode plant interactions.

So, the main aim of the current study was to estimate the potential application of microbial bioagents (arbuscular mycorrhizal fungi and T. harzianum) as biocontrol agents and biofertilizers to manage tomato root-knot nematodes (Meloidogyne javanica). Here, we studied the possible mechanisms that occur between the two bioagents and the host plant and subsequent root-knot nematode infection.

\section{Materials and Methods}

\subsection{Nematode Inoculum}

The Meloidogyne javanica nematode population was isolated from tomato plants (Lycopersicon esculentum L.) grown in an open field and maintained on susceptible host 
tomato plants in the greenhouse. For nematode inoculum preparation, the tomato root system was separated from the whole plant and washed with water to remove soil adhesion. Egg masses of M. javanica were recovered from galls of the infected tomato roots and stirred for $4 \mathrm{~min}$ in $0.5 \% \mathrm{NaOCl}$ [24]. Nematode egg suspensions were sieved through a 500 mesh sieve $(25 \mu \mathrm{m})$ and collected in sterilized water. The second stage juveniles (J2) were obtained from the incubated eggs (after 3-5 days) using a modified Baermann funnel method [25]. M. javanica inoculum was used for the pot experiment consisting of $3000 \pm 5 \mathrm{~J} 2$ dispensed in $50 \mathrm{~mL}$ of water.

\subsection{Arbuscular Mycorrhizal Inoculum}

The propagules of AMF were recovered from tomato rhizosphere soils by the wet sieve method [26]. The identification of AM fungal spores, recovered from rhizospheric soil, was performed by picking up the AMF spores from the filter paper with the help of syringe or fine point camel brush and mounting them on a glass slide with a drop of polyvinyl lactophenol (PVL) and a cover slip, then they were examined using a light microscope at $40 \times$. Subsequently, the recovered spores were identified with the help of a taxonomic manual [27]. The most abundant mycorrhizal species were Acaulospora bireticulata F.M. Rothwell \& Trappe, Entrophospora infrequens (Hall) Ames \& Schneid, Funneliformis geosporum (Nicolson \& Gerd.) Walker \& Schüßler, Funneliformis mosseae (Nicolson \& Gerd.) Walker \& Schüßler, and Gigaspora margarita Becker \& Hall.

The inoculum of mycorrhizal fungi used in the greenhouse experiments (most common mycorrhizal species from tomato plants rhizosphere) was bulked up in pot sterilized soil and grown with maize (Zea mays L.) as the trap culture. After complete life cycles of AMF (about 2 months), the maize roots were separated from the whole plants. Root segments were mixed with the soil of the experimental pots. The mycorrhizal fungal inoculum (100 g) contained mycorrhizal hyphae, colonized root segments, and $10 \pm 2$ spores/g soil was used as a bio-inoculating agent for tomato plants. In the non-mycorrhizal pots, an equivalent amount (100 g soil) of sterilized soil was added. The soil was sterilized to kill any spores of microorganisms and nematodes.

\subsection{Trichoderma harzianum Inoculum}

T. harzianum AUMC14897 was obtained from the center of Prof. A. H. Moubasher for mycological sciences (AUMMC), Assiut University. The species identification was confirmed by sequence analysis of the regions of ITS1 \& ITS4 of rDNA and the sequence was deposited in the GenBank under accession No. MZ025966.

\section{Assay for Plant Growth-Promoting and Enzymatic Activities of T. harzianum}

The bioagent $T$. harzianum was screened for plant growth-promoting trials. Indole acetic acid (IAA) production by the fungus was determined using a modified method by Glickmann and Dessaux [28]. Ammonium production was assayed through the cultivation of the fungus on peptone water medium for 4 days at $28 \pm 2{ }^{\circ} \mathrm{C}$. After the incubation period, $0.5 \mathrm{~mL}$ of Nessler's reagent was added and the obtained color (from faint yellow to deep yellow or brownish) indicated ammonia production. Proteases and lipases activity was assayed in vitro in a liquid medium [29]. The fungus was grown on potato dextrose agar (PDA) at $28^{\circ} \mathrm{C}$ for 7 days until sporulation. T. harzianum spores were collected in sterile distilled water to form a homogenous spore suspension, and then a $10 \mathrm{~mL}$ spore suspension was used as starter inoculum for liquid PD medium. After 7 days, the suspension cultures, maintained in an incubator with agitation $(150 \mathrm{rpm})$, were used to inoculate the tomato seedlings as bioagents [30]. The spore suspension concentration was adjusted to $2 \times 10^{6}$ spores $/ \mathrm{mL}$.

\subsection{Raising of Test Plants}

Tomato seeds (Solanum lycopersicum L.), cultivar Dareen F1 were used in the greenhouse pot experiment. The seeds were soaked in $70 \%$ ethanol as surface sterilization for 
$2 \mathrm{~min}$, and then the seeds were rinsed several times with sterile $\mathrm{H}_{2} \mathrm{O}$ and planted in plastic cell plug trays $(4 \times 4 \mathrm{~cm})$ packed with vermiculite. The trays were kept under greenhouse conditions for 3 weeks and irrigated regularly.

\subsection{Experimental Setup}

The pot experiment was laid out to evaluate the effects of AMF and T. harzianum on tomato growth and root-knot nematode infection in the greenhouse at the Department of Plant Pathology, Faculty of Agriculture, Assiut University, Assiut, Egypt, using a completely randomized design (CRD). Tomato seedlings were planted in pots containing a $5 \mathrm{~kg}$ mixture of loam and sandy soil $(1: 1, w / w)$. The properties of the tested soil were determined according to Jackson [31]. Five tomato seedlings were planted in each pot and they were thinned to three per pot after 6 days of planting. Pots were irrigated regularly, and plants were grown under natural conditions of light, temperature (averaged $32 / 20^{\circ} \mathrm{C}$ day/night), and $85 \%$ relative humidity.

The experiment consisted of eight treatments, (1) control of healthy plants (plants without treatments); (2) plants inoculated with mycorrhizal fungi (MY); (3) plants inoculated with T. harzianum (TH); (4) plants inoculated with both mycorrhizal fungi and $T$. harzianum (MY + TH); (5) plants treated with J2 nematodes (NE); (6) MY + NE; (7) TH + NE and (8) MY + TH + NE. The mycorrhizal and T. harzianum inocula were added to each pot and completely mixed with the soil surface during planting. The nematode inoculum was added around the root zone one week after planting. Each treatment was performed in five replicates. Plants were harvested 50 days after planting, comparable to the late vegetative stage of tomato growth.

\subsubsection{Plant Analysis}

Morphological Analysis of Tomato Plants

The effects of mycorrhizal fungi and T. harzianum on overall tomato growth, root length $(\mathrm{cm})$, shoot length $(\mathrm{cm})$, plant dry weight $(\mathrm{g} / \mathrm{plant})$, and leaf area $\left(\mathrm{cm}^{2}\right)$ were estimated in 50-day-old treated and untreated tomato plants with root-knot nematodes. Tomato shoots and roots were separated, and the length was measured. The dry weight of the tomato plants was determined after drying the plant for 2 days at $70{ }^{\circ} \mathrm{C}$. Tomato leaf area $\left(\mathrm{cm}^{2}\right)$ was measured from leaf images taken with a standard scanner using the ImageJ program (https:/ /imagej.nih.gov/ij/, accessed on 15 November 2021). The leaves were taken from the same leaf pair on the treated plants.

\section{Determination of Tomato Shoot Nutrients' Content}

Shoots of tomato plants were ground and then acid-digested $\left(2: 1 \mathrm{HNO}_{3}: \mathrm{HClO}_{4}\right)$ for $\mathrm{P}, \mathrm{K}$, and Ca concentrations using ICP (inductively coupled plasma) atomic emission spectrometry. As well, for $\mathrm{N}$ shoot content, samples were digested with $\mathrm{H}_{2} \mathrm{SO}_{4}$ following the Kjeldahl method.

Physiological Analysis of Tomato Plants

A. Photosynthetic pigments

The chlorophyll a, chlorophyll b, and carotenoid contents of the tomato plants were estimated by spectrophotometric method, elicited in $95 \%$ ethyl alcohol, and calculated as $\mathrm{mg} / \mathrm{g}$ fresh weight [32].

B. Reactive oxygen species (ROS)

The hydrogen peroxide content $\left(\mathrm{H}_{2} \mathrm{O}_{2}\right)$ in the leaves of treated and untreated tomato plants was spectrophotometrically estimated as described by Sellers [33] with minor modification. The molar absorptivity of $935 \mathrm{~L} \mathrm{~mol} / \mathrm{cm}$ was used in the calculation of $\mathrm{H}_{2} \mathrm{O}_{2}$ as $\mu \mathrm{mole} / \mathrm{g}$ FW.

C. Lipid peroxidation content

Lipid peroxidation (malondialdehyde (MDA)) was detected in tomato leaves using the thiobarbituric acid reaction by monitoring malondialdehyde formation as explained by 
Hodges et al. [34]. The level of lipid peroxidation was expressed as nmol/g FW of MDA formed using an extinction coefficient of $155 \mathrm{mM} / \mathrm{cm}$.

\section{Antioxidant enzymes}

Fresh tomato leaves $(0.5 \mathrm{~g})$ were ground to a fine powder in liquid $\mathrm{N}_{2}$, and then homogenized in $5 \mathrm{~mL}$ of $100 \mathrm{mM}$ potassium phosphate buffer ( $\mathrm{pH} 7.8$ ) containing $0.1 \mathrm{mM}$ ethylenediamine tetra-acetic acid, disodium salt $\left(\mathrm{Na}_{2}-\mathrm{EDTA}\right)$, and $0.1 \mathrm{~g}$ polyvinylpyrrolidone (PVP). The homogenate was centrifuged at $18,000 \mathrm{rpm}$ for $10 \mathrm{~min}$ at $4{ }^{\circ} \mathrm{C}$ and the supernatants were collected and used for the assays of catalase (CAT; EC 1.11.1.6) according to the modified method of Aebi [35] and guaiacol peroxidase (GPX; EC 1.11.1.7) according to the method of Tatiana et al. [36]. The specific activity was expressed as units/mg protein. Protein concentrations in the enzyme extract were determined by the method of Lowry et al. [37].

E. Total phenolic content

Total phenolic content was calculated based on the Sampietro et al. [38] method using the Folin-Ciocalteu reagent on the leaves' methanolic extract, and the data was expressed as $\mathrm{mg} / \mathrm{gm}$ FW using gallic acid as a standard curve.

F. Lignin content

Lignin content in a tomato root was determined according to a modified method of Dence [39].

G. Assay of hydrolytic enzymes in plant roots

One gram of a tomato plant's roots from each treatment was ground in $10 \mathrm{~mL}$ phosphate buffer, and then the root extracts containing crude enzymes were centrifuged at $10,000 \mathrm{rpm}$ for $3 \mathrm{~min}$. Protease and lipase enzyme-specific activities were assayed on the tomato root extract supernatant as described in our published paper [29].

\subsubsection{Nematode Infection Parameters}

The root-knot nematodes' penetration rates were determined in treated tomato plant's roots at $0,5,10,15$, and 20 days after $M$. javanica inoculation. Fifty days after nematode inoculation, the plants were uprooted and the soil adhering to their roots was removed $(100 \mathrm{~g} / \mathrm{pot})$ by agitation in water. The population density of J2 in the soil, the number of galls, females, and egg masses were determined in root samples stained with acid fuchsin lactophenol. Counting was done with the aid of a dissecting microscope and a hand tally counter.

Nematode penetration (NP) $(\%)=($ No. of nematode juveniles in each treatment $/$ No. of nematode juveniles added) $\times 100$

The reproduction factor $(\mathrm{RF})=\mathrm{Pf} / \mathrm{Pi}$,

where Pf is the No. of nematode juveniles at 50 days and Pi is the No. of nematode juveniles used in soil infestation.

Nematode reduction $(\%)=(\mathrm{C} 1-\mathrm{C} 2 / \mathrm{C} 1) \times 100$, where $\mathrm{C} 1=$ No. of nematode juveniles in control and $\mathrm{C} 2=$ No. of nematode juveniles in treatments

\subsubsection{Evaluation of Mycorrhizal Root Colonization}

The mycorrhizal colonization of the tomato plant's roots was determined 50 days after inoculation with Acaulospora bireticulata, Entrophospora infrequens, Funneliformis geosporum, Funneliformis mosseae, and Gigaspora margarita. Twenty root segments $(2 \mathrm{~cm})$ were cleared with $\mathrm{KOH}(10 \% w / v)$ at $60^{\circ} \mathrm{C}$ for $10 \mathrm{~min}$ and then stained using Trypan blue $(0.5 \% w / v)$. The mycorrhizal tomato root colonization was evaluated by Phillips and Hayman [40]. The mycorrhizal spore count (spore density) was determined in $10 \mathrm{~g}$ dry soil by soil sieving and counting under a stereomicroscope at $40 \times$.

\subsection{Statistical Analysis}

The data were analyzed by one-way ANOVA using the software program SPSS (SPSS Inc., Chicago, IL, USA) Version 19.0. All treatments were carried out in 5 replicates $(n=5)$. 
Means were compared by Duncan's multiple range tests and statistical significance was conducted $(p<0.05)$.

\section{Results}

\subsection{Assay for Plant Growth-Promoting and Hydrolytic Enzyme Activities of the Bioagent T.} harzianum In Vitro

The biocontrol agent $T$. harzianum exhibited high potentiality for indole acetic acid production, recording $12.11 \pm 2.12 \mu \mathrm{g} / \mathrm{mL}$, as well as obvious ammonification activity, where orange precipitate formed after adding Nessler's reagent to the fungal supernatant (Table 1). The data shown in Table 1 revealed that T. harzianum exhibited a potential activity for hydrolytic enzyme production. The results exhibited that in the liquid medium, the protease and lipase activity produced by T. harzianum were $28.36 \pm 2.82$ and $12.30 \pm 0.31 \mathrm{U} / \mathrm{mL}$, respectively. Whereas the protease and lipase specific activities retained by T. harzianum were estimated to be $20.40 \pm 5.35$ and $9.50 \pm 1.45 \mathrm{U} / \mathrm{mg}$ protein, respectively (Table 1 ).

Table 1. Plant growth-promoting and hydrolytic enzyme activity of T. harzianum.

\begin{tabular}{lc}
\hline \multicolumn{1}{c}{ Assay } & Value \\
\hline Plant growth-promoting activities & \\
Indole acetic acid $(\mu \mathrm{g} / \mathrm{mL})$ & $12.11 \pm 2.12$ \\
Ammonia production & +++ \\
Hydrolytic enzyme activities & $12.30 \pm 0.31$ \\
Lipase activity $(\mathrm{U} / \mathrm{mL})$ & $9.50 \pm 1.45$ \\
Lipase specific activity $(\mathrm{U} / \mathrm{mg}$ protein) & $28.36 \pm 2.82$ \\
Protease activity $(\mathrm{U} / \mathrm{mL})$ & $20.40 \pm 5.35$ \\
Protease specific activity $(\mathrm{U} / \mathrm{mg}$ protein) & \\
\hline$+++=$ strong positive reaction.
\end{tabular}

\subsection{Effect of the Bioagents (Mycorrhizal fungi and T. harzianum) on Tomato Plant Growth In Vivo}

The physicochemical properties of the soil used in the pot experiment were analyzed and the data is presented in Table 2. The cation and anion of soil soluble salts are also presented in Table 2. The organic matter of the tested soil was $0.73 \%$, the available phosphorus value was $7.3(\mathrm{mg} / \mathrm{kg})$, and the total nitrogen content was $12.3(\mathrm{mg} / \mathrm{kg})$.

Table 2. Physicochemical parameters of soil used in pot experiment.

\begin{tabular}{lc}
\hline Parameter & Value \\
\hline $\mathrm{EC}_{1: 5}(\mathrm{dS} / \mathrm{m})$ & 3.79 \\
$\mathrm{pH}_{1: 2: 5}$ & 7.60 \\
$\mathrm{OM} \%$ & 0.73 \\
Available $\mathrm{P}(\mathrm{mg} / \mathrm{kg})$ & 7.3 \\
Total N (mg/kg) & 12.3 \\
Cations and anions (mg/100 g) & \\
$\mathrm{Ca}^{++}$ & 1.25 \\
$\mathrm{Mg}^{++}$ & 2.75 \\
$\mathrm{Na}^{+}$ & 1.12 \\
$\mathrm{~K}^{+}$ & 0.16 \\
$\mathrm{Cl}^{-}$ & 1.87 \\
$\mathrm{HCO}_{3}$ & 1.3 \\
\hline
\end{tabular}

The growth parameters (length, dry weight, and leaf area) of tomato plants infected with M. javanica were determined at the end of the experiment (Table 3). The results showed that mycorrhizal fungi, singly or in combination with $T$. harzianum, significantly improved the dry weight, and the root and shoot length of the treated plants. They increased the shoot length by $42 \%$ from the control and increased the dry weight by $131 \%$ from the control. Meanwhile, the infection with M. javanica decreased the shoot length of the plants by $11.9 \%$ from the control. The reduction of the dry weight of the infected plants was visible but not 
significant. A gradual and significant $(p<0.05)$ increase in leaf area of the plants inoculated with the mycorrhizal fungi and/or T. harzianum was observed (Figure $1 \&$ Table 3). We identified that inoculation with MY + TH exercised a synergistic effect on plant biological traits. Following dual inoculation, the plants registered higher values of root length, shoot length, dry weight, and leaf area. The nematode-infected plants recorded the lowest value of leaf area $\left(59.9 \mathrm{~cm}^{2}\right)$, while the mycorrhizal and/or T. harzianum inoculations minimized the negative effects of NE parasitism on the leaf area.

Table 3. Effect of mycorrhizal and/or T. harzianum inoculations on 50-day-old tomato plants' growth infected with $M$. javanica.

\begin{tabular}{lcccc}
\hline Treatment & $\begin{array}{c}\text { Root Length } \\
(\mathbf{c m})\end{array}$ & $\begin{array}{c}\text { Shoot Length } \\
(\mathbf{c m})\end{array}$ & Dry Weight $(\mathbf{g})$ & Leaf Area $\left.\mathbf{( c m}^{\mathbf{2}}\right)$ \\
\hline Control & $13.67 \pm 1.52^{\mathrm{a}}$ & $50.87 \pm 1.94^{\mathrm{b}}$ & $2.77 \pm 0.24^{\mathrm{a}}$ & $63.07 \pm 0.97^{\mathrm{b}}$ \\
MY & $24.17 \pm 1.90^{\mathrm{c}}$ & $60.70 \pm 2.42^{\mathrm{c}}$ & $4.07 \pm 1.16^{\mathrm{b}, \mathrm{c}}$ & $91.47 \pm 0.60^{\mathrm{d}}$ \\
TH & $16.50 \pm 1.32^{\mathrm{a}}$ & $52.87 \pm 2.01^{\mathrm{b}}$ & $3.16 \pm 0.38^{\mathrm{a}, \mathrm{b}}$ & $84.19 \pm 0.58^{\mathrm{c}}$ \\
MY + TH & $25.20 \pm 1.70^{\mathrm{c}}$ & $72.67 \pm 3.13^{\mathrm{e}}$ & $6.40 \pm 0.31^{\mathrm{d}}$ & $94.17 \pm 0.32^{\mathrm{e}}$ \\
$\mathrm{NE}$ & $13.77 \pm 1.36^{\mathrm{a}}$ & $44.80 \pm 1.67^{\mathrm{a}}$ & $2.31 \pm 0.16^{\mathrm{a}}$ & $59.93 \pm 0.36^{\mathrm{a}}$ \\
MY + NE & $19.67 \pm 1.52^{\mathrm{b}}$ & $61.63 \pm 3.27^{\mathrm{c}}$ & $4.47 \pm 0.76^{\mathrm{c}}$ & $92.83 \pm 0.32^{\mathrm{e}}$ \\
TH + NE & $16.60 \pm 1.63^{\mathrm{a}}$ & $51.23 \pm 1.88^{\mathrm{b}}$ & $3.33 \pm 0.50^{\mathrm{a}, \mathrm{b}}$ & $82.54 \pm 0.25^{\mathrm{c}}$ \\
MY + TH + NE & $21.40 \pm 1.76^{\mathrm{b}}$ & $66.50 \pm 2.50^{\mathrm{d}}$ & $5.17 \pm 0.76^{\mathrm{c}}$ & $90.77 \pm 0.73^{\mathrm{d}}$ \\
\hline
\end{tabular}

Values followed by the same letter(s) in the same column are not significantly different at $p<0.05$ using Duncan's multiple range test.

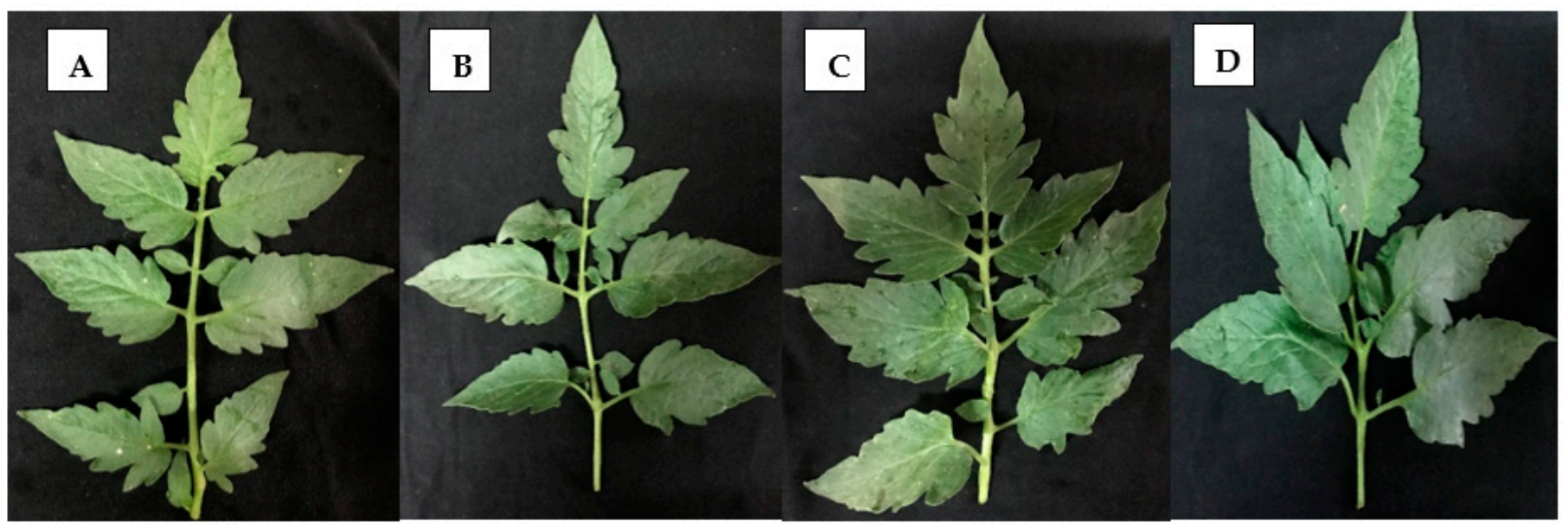

Figure 1. Morphology of tomato plants' leaves inoculated with the biocontrol agents and infected with the root-knot nematode. (A) Healthy tomato plant; (B) Nematode-infected tomato plant; (C) Infected plant inoculated with mycorrhizal fungi; (D) Infected plant inoculated with mycorrhizal fungi and T. harzianum.

\subsection{Tomato Plants' Shoot Nutrients Composition}

Tomato plants' shoot N, P, K, and Ca content as a function of nematode infection and bioagent inoculation is shown in Table 4. Overall, the mycorrhizal fungi and/or T. harzianum significantly increased shoot nutrient content $(\mathrm{N}, \mathrm{P}, \mathrm{K}, \mathrm{Ca})$, even with $M$. javanica infection. While the nematode infection alone significantly $(p<0.05)$ reduced the nutrient content to the lowest value among the treatments. Furthermore, the P content in healthy and infected plants' shoot was higher with dual inoculation, recording a 33.83\%, $41.68 \%$ increase from the control, respectively. $\mathrm{K}$ content recorded the highest value in the case of T. harzianum and/or mycorrhizal inoculation; whereas nematode infection did not affect $\mathrm{K}$ shoot content. 
Table 4. Shoot N, P, K, Ca content (mg/g DW) of tomato plants infected with $M$. javanica and inoculated with mycorrhizae and/or T. harzianum.

\begin{tabular}{lcccc}
\hline \multicolumn{1}{c}{ Treatment } & $\mathbf{N}$ & $\mathbf{P}$ & $\mathbf{K}$ & $\mathbf{C a}$ \\
\hline Control & $13.50 \pm 0.30^{\mathrm{b}}$ & $9.43 \pm 0.13^{\mathrm{b}}$ & $5.57 \pm 0.40^{\mathrm{a}}$ & $3.38 \pm 0.14^{\mathrm{b}}$ \\
$\mathrm{MY}$ & $14.45 \pm 0.17^{\mathrm{c}, \mathrm{d}, \mathrm{e}}$ & $10.68 \pm 0.18^{\mathrm{d}}$ & $7.17 \pm 0.25^{\mathrm{b}}$ & $3.85 \pm 0.27^{\mathrm{c}, \mathrm{d}}$ \\
$\mathrm{TH}$ & $14.10 \pm 0.20^{\mathrm{c}}$ & $10.07 \pm 0.19^{\mathrm{c}}$ & $10.12 \pm 0.26^{\mathrm{d}}$ & $3.46 \pm 0.05^{\mathrm{b}}$ \\
$\mathrm{MY}+\mathrm{TH}$ & $14.57 \pm 0.25^{\mathrm{d}, \mathrm{e}}$ & $12.62 \pm 0.16^{\mathrm{f}}$ & $10.25 \pm 0.28^{\mathrm{d}}$ & $4.47 \pm 0.15^{\mathrm{e}}$ \\
$\mathrm{NE}$ & $12.97 \pm 0.26^{\mathrm{a}}$ & $6.64 \pm 0.41^{\mathrm{a}}$ & $5.53 \pm 0.68^{\mathrm{a}}$ & $2.90 \pm 0.15^{\mathrm{a}}$ \\
$\mathrm{MY}+\mathrm{NE}$ & $14.75 \pm 0.13^{\mathrm{e}}$ & $13.18 \pm 0.26^{\mathrm{g}}$ & $7.27 \pm 0.25^{\mathrm{b}}$ & $3.70 \pm 0.10^{\mathrm{b}}$ \\
$\mathrm{TH}+\mathrm{NE}$ & $14.30 \pm 0.17^{\mathrm{c}, \mathrm{d}}$ & $12.13 \pm 0.21^{\mathrm{e}}$ & $9.13 \pm 0.40^{\mathrm{c}}$ & $4.13 \pm 0.32^{\mathrm{d}, \mathrm{e}}$ \\
MY + TH + NE & $15.37 \pm 0.32^{\mathrm{f}}$ & $13.36 \pm 0.15^{\mathrm{g}}$ & $10.77 \pm 0.21^{\mathrm{d}}$ & $4.43 \pm 0.23^{\mathrm{e}}$ \\
\hline
\end{tabular}

Values followed by the same letter(s) in the same column are not significantly different at $p<0.05$ using Duncan's multiple range test.

\subsection{Physiological Analysis of Tomato Plants}

\subsubsection{Photosynthetic Pigments}

Nematode infection significantly decreased the content of total chlorophyll and carotenoids; we recorded the lowest value $(5.80 \mathrm{mg} / \mathrm{g}$ FW) in the infected non-inoculated plants (Table 5). While their content improved significantly with the application of the bioagents. Compared to relevant non-inoculated tomato plants and those with T. harzianum inoculation, mycorrhizal inoculation significantly improved plant pigments content, and the dual inoculated plants had higher photosynthetic pigments contents $(7.20 \mathrm{mg} / \mathrm{g} F W)$. Leaf photosynthetic pigments' content was increased in nematode infected tomato plants that were also inoculated with the bioagents as compared with infected plants alone, thus indicating simultaneous improvement in the photosynthetic process.

Table 5. Effect of mycorrhizal and/or T. harzianum inoculations on photosynthetic pigments (mg/g fresh weight) in tomato plants infected with $M$. javanica.

\begin{tabular}{lccc}
\hline \multicolumn{1}{c}{ Treatment } & Chlorophyll a & Chlorophyll b & Carotenoids \\
\hline Control & $8.40 \pm 0.13^{\mathrm{a}}$ & $6.01 \pm 0.15^{\mathrm{a}}$ & $3.98 \pm 0.15^{\mathrm{b}}$ \\
MY & $8.80 \pm 0.09^{\mathrm{c}}$ & $7.49 \pm 0.68^{\mathrm{b}}$ & $4.82 \pm 0.17^{\mathrm{e}}$ \\
$\mathrm{TH}$ & $8.55 \pm 0.07^{\mathrm{a}, \mathrm{b}}$ & $6.37 \pm 0.11^{\mathrm{a}}$ & $4.41 \pm 0.13^{\mathrm{c}}$ \\
$\mathrm{MY}+\mathrm{TH}$ & $9.15 \pm 0.53^{\mathrm{d}}$ & $7.52 \pm 0.35^{\mathrm{b}}$ & $4.94 \pm 0.14^{\mathrm{f}}$ \\
$\mathrm{NE}$ & $7.92 \pm 0.32^{\mathrm{a}, \mathrm{b}}$ & $5.94 \pm 0.34^{\mathrm{a}}$ & $3.55 \pm 0.16^{\mathrm{a}}$ \\
$\mathrm{MY}+\mathrm{NE}$ & $8.77 \pm 0.14^{\mathrm{c}}$ & $6.14 \pm 0.24^{\mathrm{a}}$ & $4.46 \pm 0.12^{\mathrm{c}, \mathrm{d}}$ \\
TH + NE & $8.80 \pm 0.32^{\mathrm{c}}$ & $6.02 \pm 0.05^{\mathrm{a}}$ & $4.05 \pm 0.16^{\mathrm{b}}$ \\
MY + TH + NE & $9.31 \pm 0.16^{\mathrm{d}}$ & $6.31 \pm 0.10^{\mathrm{a}}$ & $4.66 \pm 0.14^{\mathrm{d}, \mathrm{e}}$ \\
\hline
\end{tabular}

Values followed by the same letter(s) in the same column are not significantly different at $p<0.05$ using Duncan's multiple range test.

\subsubsection{Reactive Oxygen Species (ROS)}

Plants infected with $M$. javanica (NE) stimulated the oxidative burst in the infected tomato plants recording an increase of $\mathrm{H}_{2} \mathrm{O}_{2}$ content, which is an oxidative stress index (Figure 2A). The highest value of $\mathrm{H}_{2} \mathrm{O}_{2}$ occurred in the infected and non-inoculated plants that was 2-fold from the control. The reduction in $\mathrm{H}_{2} \mathrm{O}_{2}$ content was significant in the infected tomato plants inoculated with the two bioagents, recording the highest reduction in the infected dual inoculated plants $(-49 \%)$. 

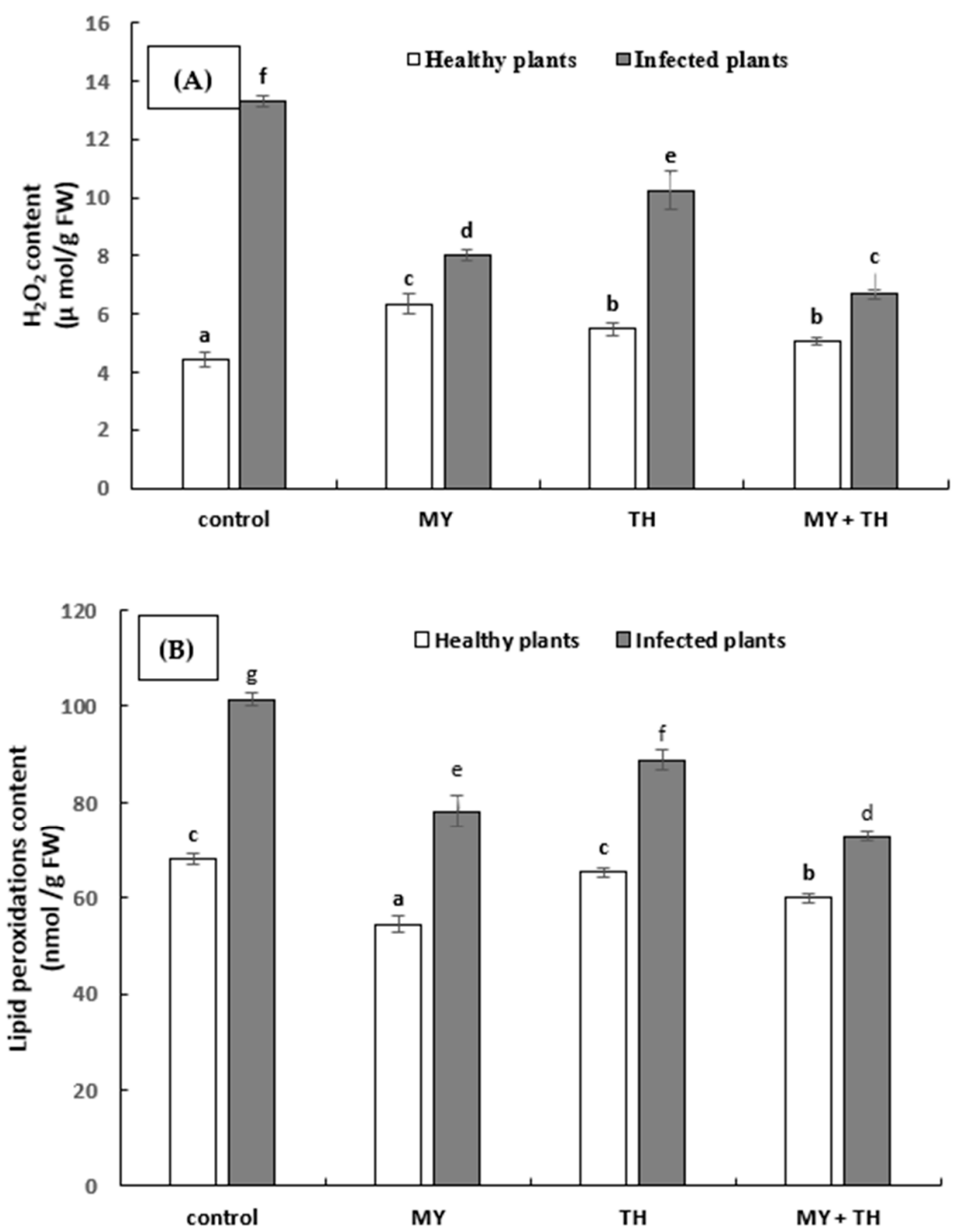

Figure 2. (A) Hydrogen peroxide $\left(\mathrm{H}_{2} \mathrm{O}_{2}\right)$ and (B) lipid peroxidation (malondialdehyde (MDA)) contents as oxidative stress indicators of healthy and infected tomato plants inoculated with mycorrhizal fungi (MY), T. harzianum (TH), and AMF + TH. Vertical bars indicate $\pm \mathrm{SE}(n=5)$; columns followed by different letters are significantly different at $p<0.05$.

\subsubsection{Lipid Peroxidation Content}

The malondialdehyde (MDA) content in tomato plants indicates the lipid peroxidation process. Figure $2 \mathrm{~B}$ shows that the MDA content of the tomato plants infected with $M$. javanica was noticeably increased compared with the inoculated plants with bioagents, which lowered the MDA content in plants. The lowest MDA content was detected in nonmycorrhizal-treated plants $(54.5 \mathrm{nmol} / \mathrm{g} \mathrm{FW})$ and the highest content was in the infected non-inoculated plants $(101.54 \mathrm{nmol} / \mathrm{g} \mathrm{FW})$.

\subsubsection{Antioxidant Enzymes}

The antioxidant enzyme activity in tomato leaves is presented in Figure 3. Data showed catalase (CAT) and glutathione peroxidase (GPX) enzyme activity in the infected tomato plants and the plants inoculated with mycorrhizae and/or T. harzianum. There was a reduction in CAT activity in the nematode-infected non-inoculated plants compared with the infected and inoculated plants. Meanwhile, CAT activity significantly increased by dual inoculation; we recorded the highest value in the infected and dual inoculated plants (131.57\% increase from the control). The glutathione peroxidase (GPX) enzyme content in the tomato plants infected with NE significantly increased because of the bioagents' inoculation. The infected and non-inoculated plants had no significant effect on GPX 
content as compared with the healthy non-inoculated plants. The highest value of GPX was recorded in the infected and dual inoculated plants (133.59 \% increase from the control).
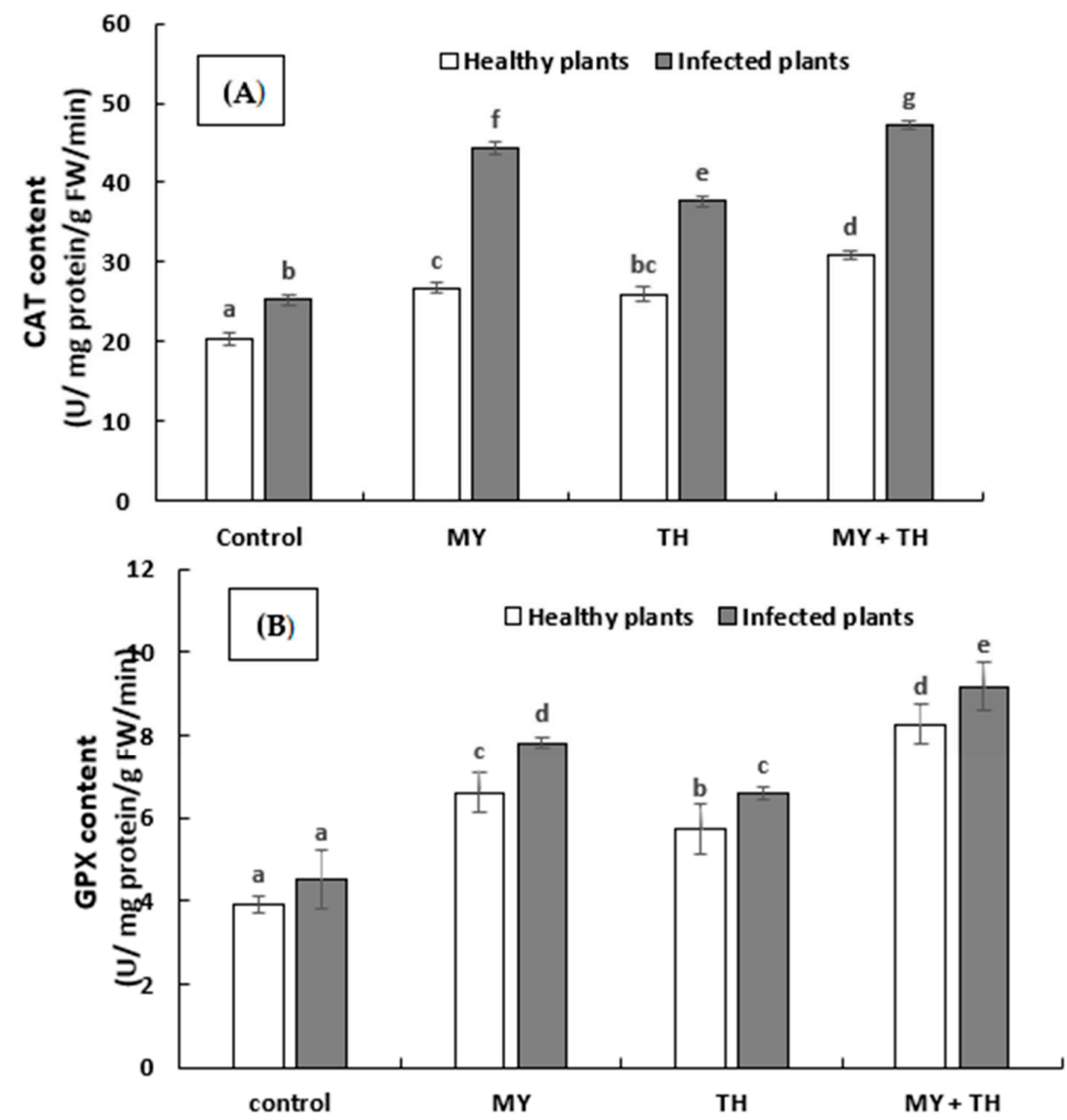

Figure 3. Antioxidant enzyme content: (A) Catalase (CAT) and (B) glutathione peroxidase (GPX) of healthy and infected tomato plants inoculated with mycorrhizal fungi (MY), T. harzianum (TH), and $\mathrm{AMF}+\mathrm{TH}$. Vertical bars indicate $\pm \mathrm{SE}(n=5)$; columns followed by different letters are significantly different at $p<0.05$.

\subsubsection{Total Phenolic and Lignin Contents}

The bioagents (mycorrhizae and T. harzianum) stimulated the production of total phenolics in tomato plant cells compared with the infected non-inoculated plants (Figure 4A). The highest phenolic content was recorded in the infected dual inoculated plants $(1.02 \mathrm{mg} / \mathrm{g}$ FW), followed by the mycorrhizal-infected plants $(0.92 \mathrm{mg} / \mathrm{g} \mathrm{FW})$. Lignin content as a secondary metabolite is presented in Figure 4B. Lignin biosynthesis significantly increased in infected and non-inoculated tomato plants, where we recorded the highest value $(130 \%$ from the control). Furthermore, lignin content was reduced significantly in dual inoculated plants. 

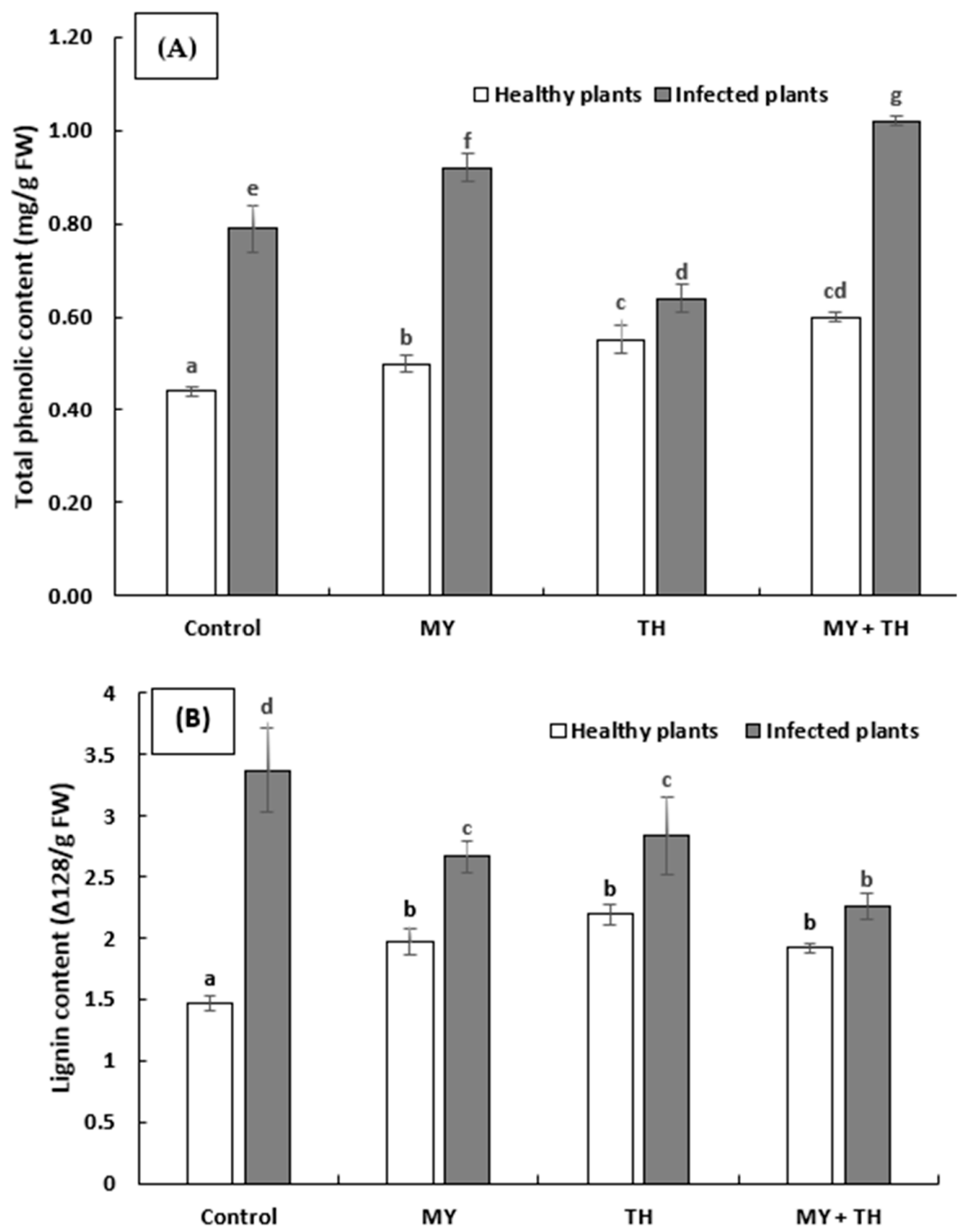

Figure 4. (A) Total phenolic content and (B) lignin content of healthy and infected tomato plants inoculated with mycorrhizal fungi (MY), T. harzianum $(\mathrm{TH})$, and $\mathrm{AMF}+\mathrm{TH}$. Vertical bars indicate $\pm \mathrm{SE}$ $(n=5)$; columns followed by different letters are significantly different at $p<0.05$.

\subsubsection{Hydrolytic Enzyme Activity in Tomato Plants' Roots}

The obtained data illustrated that the lowest hydrolytic enzyme activity was recorded in healthy tomato plants compared with the infected plants. Meanwhile, the bioagents, applied individually or in combination, exhibited a significant increase $(p<0.05)$ in the hydrolytic enzyme activity of tomato root extracts in the infected plants compared with the healthy plants (Figure 5). Similarly, root extracts of the infected and inoculated tomato plants revealed the highest protease and lipase enzyme activity with both bioagents, arbuscular mycorrhizal fungi and T. harzianum. 

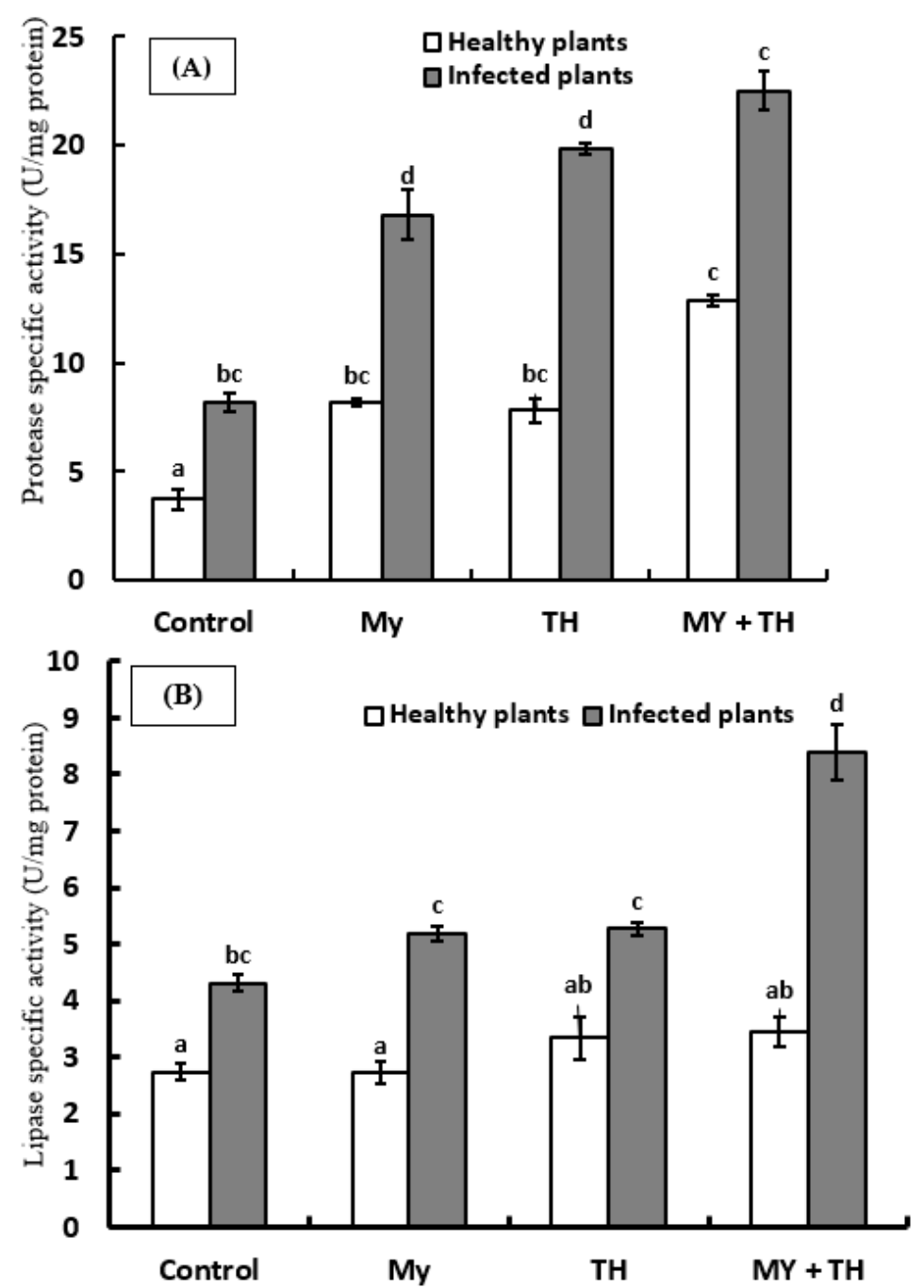

Figure 5. Hydrolytic enzyme activity in tomato plants' roots: (A) Protease and (B) lipase in healthy and infected tomato plants' roots inoculated with mycorrhizal fungi (MY), T. harzianum (TH), and $\mathrm{AMF}+\mathrm{TH}$. Vertical bars indicate $\pm \mathrm{SE}(n=5)$; columns followed by different letters are significantly different at $p<0.05$.

\subsection{Nematode Infection}

Five days after nematode inoculation, the penetration rates (ratio of the number of penetrated nematodes to the number of added nematodes) were determined in all treatments (Figure 6). The penetration rate of nematodes in all treatments improved over time, with the highest improvement (6.2-9.03\%) towards the end of the 20 days. The penetration rate in the infected and non-inoculated control was $9 \% 20$ days after nematode inoculation, while it reached $6 \%$ in the case of the dual bioagents' treatment. Table 6 illustrates the potential of the two bioagents to reduce the populations of nematodes. By applying mycorrhizal fungi and/or T. harzianum, the number of larvae, females, egg masses, and galls was significantly reduced. The highest juveniles' number was detected in the infected and non-inoculated tomato plants, while the lowest number of J2s was recorded in the case of $\mathrm{MY}$ and $\mathrm{MY}+\mathrm{TH}$, corresponding to $45 \%$ and $55 \%$ reduction from the control, respectively (Figure 7). The number of females and egg masses produced by M. javanica was high in the infected and non-inoculated tomato plants (infected control) (Table 6). It was found that the number of females and egg masses in the inoculated and infected plants was significantly lower than that of the infected control, and the dual inoculation achieved the greatest reduction in numbers. Compared with the infected control, mycorrhizal fungi and T. harzianum caused a $68 \%$ reduction in the number of 
females and a $43 \%$ reduction in egg masses (Figure 7). In pots infected with NE, more galls on the tomato plants' roots were found on non-inoculated plants (Table 6), of which the highest number of galls (105/root) was recorded. Application of mycorrhizal fungi alone or combined with $T$. harzianum reduced the formation of galls by $40.63 \%$ and $52.38 \%$ from the infected control, respectively. The reproduction factor (RF) was calculated for all treatments and was significantly different. As the highest reproduction factor $(\mathrm{RF}=3.24)$ was recorded in the infected control. The dual inoculation showed the lowest RF (1.46) followed by the single inoculation.

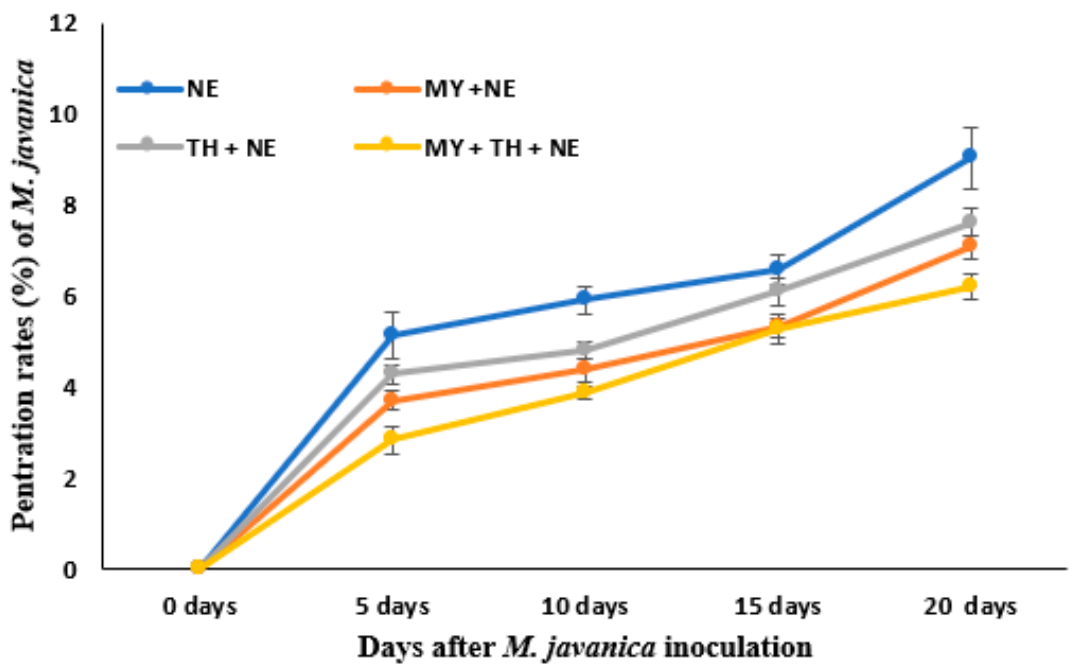

Figure 6. Root-knot nematode penetration rates (\%) in tomato plants' infected roots as affected by inoculation with mycorrhizal fungi (MY), T. harzianum (TH), and AMF + TH. Vertical bars indicate \pm SE $(n=5)$.

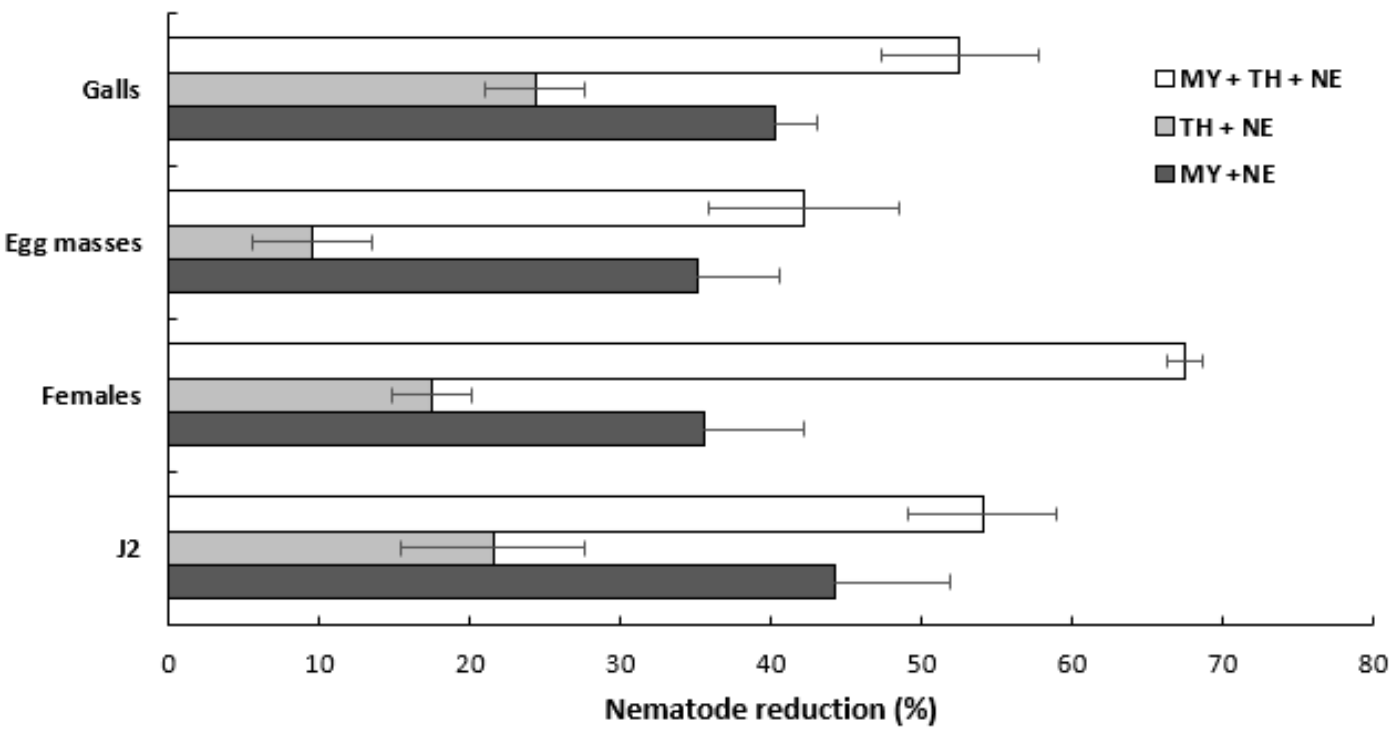

Figure 7. Percentage of juvenile, female, egg masse, and gall reduction in tomato infected roots as affected by inoculation with mycorrhizal fungi (MY), T. harzianum (TH), and AMF + TH. Vertical bars indicate $\pm \operatorname{SE}(n=5)$. 
Table 6. Effect of the biocontrol agents alone or in combination on the population of nematodes.

\begin{tabular}{lccccc}
\hline \multicolumn{1}{c}{ Treatment } & J2/100 g Soil & Females/Root & Egg Masses/Root & Galls/Root & RF \\
\hline NE & $242.67 \pm 9.69^{\mathrm{c}}$ & $35.67 \pm 6.03^{\mathrm{c}}$ & $142.80 \pm 11.37^{\mathrm{b}}$ & $105.00 \pm 8.00^{\mathrm{c}}$ & $3.24 \pm 0.39^{\mathrm{c}}$ \\
$\mathrm{MY}+\mathrm{NE}$ & $133.00 \pm 13.46^{\mathrm{a}}$ & $23.00 \pm 4.00^{\mathrm{b}}$ & $91.67 \pm 7.02^{\mathrm{a}}$ & $62.33 \pm 4.51^{\mathrm{a}}$ & $1.78 \pm 0.20^{\mathrm{a}}$ \\
$\mathrm{TH}+\mathrm{NE}$ & $193.33 \pm 14.59^{\mathrm{b}}$ & $29.33 \pm 4.04^{\mathrm{b}, \mathrm{c}}$ & $128.33 \pm 7.25^{\mathrm{b}}$ & $79.33 \pm 8.50^{\mathrm{b}}$ & $2.58 \pm 0.33^{\mathrm{b}}$ \\
$\mathrm{MY}+\mathrm{TH}+\mathrm{NE}$ & $109.00 \pm 10.58^{\mathrm{a}}$ & $11.33 \pm 3.21^{\mathrm{a}}$ & $81.67 \pm 9.07^{\mathrm{a}}$ & $50.00 \pm 6.56^{\mathrm{a}}$ & $1.46 \pm 0.14^{\mathrm{a}}$ \\
\hline
\end{tabular}

Values followed by the same letter(s) in the same column are not significantly different at $p<0.05$ using Duncan's multiple range test. RF is the nematode reproduction factor.

\subsection{Mycorrhizal Colonization}

The mycorrhizal colonization of the tomato plants' roots was determined with the application of T. harzianum in the presence or absence of $M$. javanica (Table 7). There was a significant difference in root colonization between healthy and infected tomato plants, with mycorrhizal colonization being higher in the infected tomato plants. The tomato plants' roots inoculated with the mycorrhizal fungi were occupied by intra-, inter-, and extraradical hyphae, arum-type of arbuscules, and vesicles (Figure 8). Meanwhile, the intra- and inter-radical hyphae grew from cell to cell within the intercellular space, penetrating the cell walls and forming arbuscules (Figure 8). The hyphal colonization of tomato plants inoculated with a mixture from Acaulospora bireticulata, Entrophospora infrequens, Funneliformis geosporum, Funneliformis mosseae, and Gigaspora margarita ranged from 70-95\%, and the highest value was recorded in the tomato plants inoculated with the mycorrhizal fungi. Arbuscular root colonization of the tomato plants was positively affected by nematode infection, of which the highest colonization was reported in the infected mycorrhizal-inoculated plants. The vesicle colonization was significantly influenced by nematode infection, ranging from $45-70 \%$, of which the lowest value occurred in infected-mycorrhizal tomato plants (30.76\% decrease from healthy mycorrhizal plants). The numbers of glomerospores in the tomato plants were significantly increased by the nematode infection (Table 7). The highest mycorrhizal spore density was recorded in the rhizosphere soil of dual inoculated plants.

Table 7. Percentage (\%) of root colonization (hyphal, arbuscular, vesicle colonization) of 50-day-old tomato plants inoculated with mycorrhizae and/or T. harzianum and infected with M. javanica.

\begin{tabular}{lcccc}
\hline Treatment & $\begin{array}{c}\text { Hyphal } \\
\text { Colonization }\end{array}$ & $\begin{array}{c}\text { Arbuscular } \\
\text { Colonization }\end{array}$ & $\begin{array}{c}\text { Vesicle } \\
\text { Colonization }\end{array}$ & $\begin{array}{c}\text { Mycorrhizal } \\
\text { Spore Density }\end{array}$ \\
\hline MY & $73.3^{\mathrm{a}, \mathrm{B}}$ & $50.0^{\mathrm{a}, \mathrm{A}}$ & $65.0^{\mathrm{b}, \mathrm{B}}$ & $55.7^{\mathrm{a}}$ \\
$\mathrm{MY}+\mathrm{NE}$ & $91.7^{\mathrm{b}, \mathrm{C}}$ & $70.0^{\mathrm{b}, \mathrm{B}}$ & $50.0^{\mathrm{a}, \mathrm{A}}$ & $64.2^{\mathrm{a}, \mathrm{b}}$ \\
$\mathrm{MY}+\mathrm{TH}$ & $70.0^{\mathrm{a}, \mathrm{B}}$ & $48.3^{\mathrm{a}, \mathrm{A}}$ & $70.0^{\mathrm{b}, \mathrm{B}}$ & $66.6^{\mathrm{a}, \mathrm{b}}$ \\
$\mathrm{MY}+\mathrm{TH}+\mathrm{NE}$ & $95.0^{\mathrm{b}, \mathrm{C}}$ & $78.3^{\mathrm{b}, \mathrm{B}}$ & $45.0^{\mathrm{a}, \mathrm{A}}$ & $73.3^{\mathrm{c}}$ \\
\hline
\end{tabular}

Means within each column followed by the same lowercase letter (for each parameter) and means within each row followed by the same uppercase (for each treatment in colonization parameter) are not significantly different at $p<0.05$ using Duncan's multiple range test. 


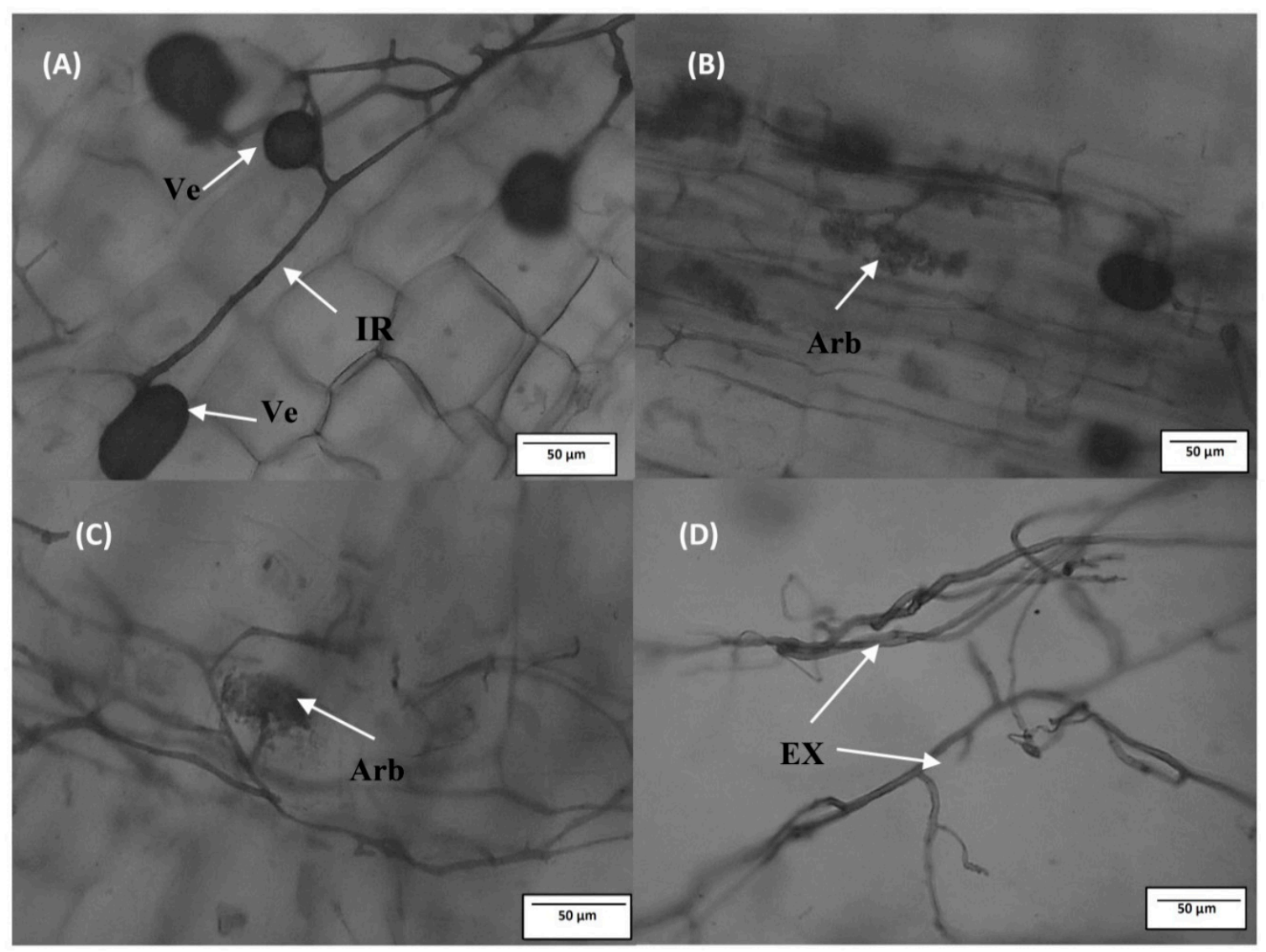

Figure 8. Root colonization patterns of 50-day-old tomato plants inoculated with dual inoculations under nematode infection: (A) vesicles (Ve) and intra-radical hyphae (IR); (B,C) arum-type of arbuscules (Arb); (D) extra-radical hyphae (EX).

\section{Discussion}

Plants inoculated with beneficial, indigenous microbes have been recommended for increasing the sustainability of plant yield and protecting plants against stress [41]. Furthermore, the interaction between these beneficial microorganisms and the plant rhizosphere enhances plant growth, nutrient acquisition, yield, and soil energy conversion. Mycorrhizal fungi and T. harzianum are well-known as natural, biosafe biocontrol agents of nematode infections. Root-knot nematodes sorely affect tomato plants' growth and yield all over the world $[42,43]$. Our study reported that mycorrhizal fungi and T. harzianum can limit the growth and reproduction of the nematodes and reduce their parasitism in tomato plants' roots.

In the current study, the biocontrol agent $T$. harzianum showed high potentiality to produce plant growth-promoting compounds, as well as a potential for encouraging hydrolytic enzyme production. Nieto-Jacobo et al. [44] stated that Trichoderma species are soil-borne fungi that are commonly employed for various plant health benefits, due to their potentiality for improved plant growth, abiotic stress tolerance, and disease resistance. The capability of various Trichoderma species to produce the plant phytohormone auxins (indole-3-acetic acid) that is determined by the presence of the main precursor L-tryptophan, which is produced as plant exudates [12,45]. Indole acetic acid (IAA) production by Trichoderma explained their efficiency in promoting plant root growth that could change root architecture, leading to increased root mass and subsequently increased the root area for beneficial microbial colonization and enhanced nutrient uptake [46]. Furthermore, ammonia production by soil microbes showed important properties in stimulating nitrogen assimilation and plant development [12,47]. Interestingly, Zhang et al. [7] reported that the hydrolytic enzyme activity of Trichoderma species may explain the direct mechanism 
of Trichoderma-nematode interaction through the first step of Trichoderma parasitism on nematodes by hydrolyzing the nematode eggs and the second-stage juveniles. So, for disturbing nematode eggs and juveniles and consequently controlling the plant pathogenic nematodes, a combination of lytic enzymes including proteases, chitinases, and lipases are required [48].

In the present study, dual inoculation with mycorrhizal fungi and T. harzianum improved the nutrient acquisition and growth of tomato plants. The use of dual inoculation favored improvement in the shoot length and dry weight more than the single inoculation. In the same context as our finding, dual inoculation with Glomus mosseae and plant growthpromoting rhizobacteria enhanced tomato plant growth more than single inoculation [49]. In our study, the interaction between tomato plants and nematode pathogens led to a morphological and physiochemical change in the tomato host. M. javanica infection significantly diminished the tomato plants' growth and shoot nutrient composition, while the bioagents' application reduced the harmful effect of the nematode infection. The biocontrol efficiency of mycorrhizal fungi against nematodes has been recorded previously in tomato plants [50]. Rhizophagus intraradices and Funneliformis mosseae decreased nematode tomato root penetration by Nacobbus aberrans [51]. Mycorrhizal fungi can improve the vitality of the host plants by enhancing nutrient uptake, mainly phosphorus, nitrogen, and potassium, and increase water-use efficiency. Improved branching and growth of mycorrhizal roots may increase the plants' tolerance towards NE infection and balances the inhibited root branching caused by nematodes [52]. Meanwhile, mycorrhizal bioprotective effects were reported to be systemically induced as they act through the host plant [8]. Consequently, in the current study, the enhancement effects on plant growth following inoculation with T. harzianum, were also explained by improvement of the plant's nutritional status. In addition, mycorrhizal fungi and T. harzianum effectively take possession of the rhizosphere and inhibit nematode populations within the phytobiome, hence, increasing every aspect of tomato growth.

Our results proved that photosynthetic pigments increased in the infected tomato plants that were also inoculated with the bioagents, thus indicating simultaneous improvement in the photosynthetic process. Mycorrhizal fungi being natural root symbionts, support essential inorganic nutrients uptake to host plants, thereby causing mycorrhizal plants to have higher chlorophyll content and higher photosynthetic activity. While in the infected and non-inoculated plants, photosynthetic pigments were significantly reduced, as previously reported [53]. The impairment of the chlorophyll and carotenoids mainly happened due to the suppression of enzymatic activities implicated in the violaxanthin cycle, which disturbed the photosynthetic apparatus stabilization [54].

The reactive oxygen species (ROS) contents are stimulated during environmental stresses, which could cause damage to plant tissues, deterioration of lipid and protein, DNA mutation, the disordering of cell organelle, and decay of the photosynthetic apparatus [55]. Plant oxidation, non-enzymatic and enzymatic, has been reported as plant oxidative response systems that interfered with the aerobic process to minimize the oxidative cleavage due to more ROS production. Catalase (CAT) and guaiacol peroxidase (GPX) were reported as protective oxidative enzymes in plants. In our study, NE stimulated the oxidative burst in the infected and non-inoculated plants, recording the highest value in $\mathrm{H}_{2} \mathrm{O}_{2}$ and MDA content. Similar to other pathogen stress, nematode infection produces excessive free radicles such as $\mathrm{H}_{2} \mathrm{O}_{2}$, which accumulates during hypertrophy and cell death [8]. Mycorrhizal plant resistance against nematodes occurs through improvement in the systematic defensive capacity of roots due to the activation of the genes that encoded chitinases, pathogenesis-related proteins, enzymes implicated in the detoxification of ROS, enzymes implicated in lignin biosynthesis, and in the pathway of the shikimate, which, in turn, develop precursors of different aromatic secondary metabolites against the infection of nematodes [16,19]. Our results demonstrated that CAT and GPX enzyme activity was enhanced in infected dual inoculated tomato plants to eliminate the toxicity of $\mathrm{H}_{2} \mathrm{O}_{2}$. Similar to our results, the systematic resistance developed by mycorrhizal fungi to 
reduce nematode infection occurred through the activity of phenolics and plant defense enzymes with the reduction in MDA and $\mathrm{H}_{2} \mathrm{O}_{2}$ contents in tomato plants inoculated with Rhizophagus irregularis and enhanced plant growth [17].

In the present study, lignin content of the infected tomato plants was significantly increased. Infection and reproduction by NE are influenced by changes in lignin composition or content. Nematodes create their constant feeding places inside the vascular cylinder, which is the main location of the roots' secondary wall formation and lignification [56]. The change in lignin content is an important factor that explains the structural differences in root cell walls: if its content increased, it implies that root cell walls lignify, thicken, and create barriers to defend against the invasion of the pathogen. The inoculated plants with the bioagents compared with infected tomato plants showed a significant reduction in the lignin content due to decreased nematode infection and gall numbers.

Furthermore, the current study revealed that the hydrolytic enzyme activity in tomato plant roots was significantly enhanced in the infected plants inoculated with the bioagents. Zhang et al. [7] stated that the potential effect of bioagents may be due to the direct parasitism mechanisms that have lethal impacts on the nematode eggs and J2 activities. Consequently, an increase of extracellular hydrolytic enzyme activity was reported, which allowed a direct effect on nematode eggshells and penetration of the eggs, leading to a decrease in the number of nematode eggs capable of hatching and, thus, the number of infective juveniles (J2) [7]. Therefore, the bioagents (MY and TH) could be applied as a biocontrol agent for the management of nematode infections in economic crop plants.

In the present study, the simultaneous tomato root inoculation by MY and TH significantly reduced the nematode penetration rates and populations, indicative of indirect and direct biocontrol activity against NE as previously reported [43]. The effect of mycorrhizal and dual inoculations was significantly pronounced on juveniles, the abundant and important life stage in nematode inoculum. These results may be related to difficult nematode migration towards the roots because the bioagents occupied the rhizosphere and therefore caused difficulty in finding feeding space, so a reduction in nematode stage developments and gall formation occurred. Compared with other nematode populations, juveniles were the most active and greatest food seekers, which resulted in a higher root penetration rate [57]. The direct mechanism of nematode population reduction by T. harzianum inoculation occurred by fungal hyphae penetrating the egg mass matrix of nematodes and reducing nematode hatching [58], or by the production of secondary fungal toxic metabolites, which prevented nematode penetration and infection [59].

Arbuscular root colonization of tomato plants was positively affected by nematode infection, as the highest colonization was reported in infected mycorrhizal plants. Furthermore, the mycorrhizal spore density increased under nematode infection. Space competition between glomerospores and endoparasitic nematodes could be related to increasing mycorrhizal colonization due to competing for space and photosynthates. This may occur in plants under stress. Competition for space indicates higher mycorrhizal colonization and might lead to a higher level of mycorrhizal mediated biocontrol [60]. Mycorrhizal colonization is characterized by the presence of a high amount of arbuscules, which seems to be a requirement for biocontrol.

\section{Conclusions}

The biological approaches for plant-parasitic-nematodes constitute an effective alternative to the conventional toxic chemical nematicides. The use of different species of mycorrhizal fungi, in addition to T. harzianum, aims at ecofriendly protection, increased soil fertility, and improved plant growth and, thus, has an advantage to sustainable agriculture. T. harzianum exhibited a high potentiality to produce plant growth promoting compounds (indole acetic acid and ammonia). As well, T. harzianum revealed varied enzymatic activities (protease and lipase) that may illustrate their hydrolytic abilities against nematode eggs and juveniles. Furthermore, in bioagent inoculated tomato plants, the penetration rates of nematodes, juveniles and females numbers, egg and gall mass were reduced. Furthermore, 
glutathione peroxidase and catalase enzymatic activities were enhanced. So, the applied bioagents revealed various effective strategies for the management of nematodes, including the production of secondary metabolites, hydrolytic enzymes, as well as providing greater nutrient and water uptake to the host plant, altering root morphology and rhizospheric interactions and consequently competing for colonization/infection sites or photosynthates. Moreover, the biocontrol agents stimulate induced systematic resistance in plants against infection by pathogen and/or pests. In summary, the use of biocontrol agents in combination is a promising biocontrol tactic in agriculture against plant-parasitic nematodes that may enhance the feasibility and commercial application of ecofriendly biofertilizers in agriculture cropping systems.

Author Contributions: N.A.N., E.A.H., R.S. and R.G.M.: experimental design, methodology, software, formal analysis, data curation, writing — original draft preparation, writing—review and editing; M.H., A.M.E.-Z. and Y.S.M.: supervision, formal analysis, investigation, data curation, writingreview and editing; S.A.: revised the manuscript, visualization, project administration, funding acquisition. All authors have read and agreed to the published version of the manuscript.

Funding: This research was funded by the Deputyship for Research \& Innovation, Ministry of Education, Saudi Arabia, under the project number IFP-KKU-2020/2.

Institutional Review Board Statement: Not applicable.

Informed Consent Statement: Not Applicable.

Data Availability Statement: The following information was supplied regarding data availability: The sequencing data of the fungal strain Trichoderma harzianum strain AUMC 14897 were deposited in the NCBI website (https: / / www.ncbi.nlm.nih.gov/nuccore/MZ025966), accessed on 24 April 2021 under the accession number MZ025966.

Acknowledgments: The authors extend their appreciation to the Deputyship for Research \& Innovation, Ministry of Education, Saudi Arabia, for funding this research work through the project number IFP-KKU-2020/2.

Conflicts of Interest: The authors declare no conflict of interest.

\section{References}

1. Gamalero, E.; Glick, B.R. The use of plant growth-promoting bacteria to prevent nematode damage to plants. Biology $2020,9,381$. [CrossRef]

2. Bradshaw, C.J.; Leroy, B.; Bellard, C.; Roiz, D.; Albert, C.; Fournier, A.; Barbet-Massin, M.; Salles, J.M.; Simard, F.; Courchamp, F. Massive yet grossly underestimated global costs of invasive insects. Nat. Commun. 2016, 7, 12986. [CrossRef] [PubMed]

3. Siddique, S.; Grundler, F.M. Parasitic nematodes manipulate plant development to establish feeding sites. Curr. Opin. Microbiol. 2018, 46, 102-108. [CrossRef] [PubMed]

4. Palomares-Rius, J.E.; Escobar, C.; Cabrera, J.; Vovlas, A.; Castillo, P. Anatomical alterations in plant tissues induced by plantparasitic nematodes. Front. Plant Sci. 2017, 8, 1987. [CrossRef] [PubMed]

5. FAO. The Future of Food and Agriculture. Rome: Trends and Challenges; FAO: Rome, Italy, 2017.

6. Mhatre, P.H.; Karthik, C.; Kadirvelu, K.; Divya, K.L.; Venkatasalam, E.P.; Srinivasan, S.; Ramkumar, G.; Saranya, C.; Shanmuganathan, R. Plant growth promoting rhizobacteria (PGPR): A potential alternative tool for nematodes bio-control. Biocatal. Agric. Biotechnol. 2019, 17, 119-128. [CrossRef]

7. Zhang, S.; Gan, Y.; Ji, W.; Xu, B.; Hou, B.; Liu, J. Mechanisms and characterization of Trichoderma longibrachiatum T6 in suppressing nematodes (Heterodera avenae) in wheat. Front. Plant Sci. 2017, 8, 1491. [CrossRef]

8. Poveda, J.; Abril-Urias, P.; Escobar, C. Biological control of plant-parasitic nematodes by filamentous fungi inducers of resistance: Trichoderma, mycorrhizal and endophytic fungi. Front. Microbiol. 2020, 11, 992. [CrossRef]

9. Xiang, N.; Lawrence, K.S.; Donald, P.A. Biological control potential of plant growth-promoting rhizobacteria suppression of Meloidogyne incognita on cotton and Heterodera glycines on soybean: A review. J. Phytopath. 2018, 166, 449-458. [CrossRef]

10. Ferlian, O.; Biere, A.; Bonfante, P.; Buscot, F.; Eisenhauer, N.; Fernandez, I.; Hause, B.; Herrmann, S.; Krajinski-Barth, F.; Meier, I.C.; et al. Growing research networks on mycorrhizae for mutual benefits. Trends Plant Sci. 2018, 23, 975-984. [CrossRef]

11. Bagy, H.M.K.; Hassan, E.A.; Nafady, N.A.; Dawood, M.F. Efficacy of arbuscular mycorrhizal fungi and endophytic strain Epicoccum nigrum ASU11 as biocontrol agents against blackleg disease of potato caused by bacterial strain Pectobacterium carotovora subsp. atrosepticum PHY7. Biol. Control 2019, 134, 103-113. [CrossRef] 
12. Nafady, N.A.; Hashem, M.; Hassan, E.A.; Ahmed, H.A.; Alamri, S.A. The combined effect of arbuscular mycorrhizae and plantgrowth-promoting yeast improves sunflower defense against Macrophomina phaseolina diseases. Biol. Control 2019, $138,104049$. [CrossRef]

13. Wani, K.A.; Manzoor, J.; Shuab, R.; Lone, R. Arbuscular mycorrhizal fungi as biocontrol agents for parasitic nematodes in plants. In Mycorrhiza-Nutrient Uptake, Biocontrol, Ecorestoration; Springer: Cham, Switzerland, 2017; pp. 195-210.

14. Hohmann, P.; Messmer, M.M. Breeding for mycorrhizal symbiosis: Focus on disease resistance. Euphytica 2017, $213,113$. [CrossRef]

15. Jacott, C.N.; Murray, J.D.; Ridout, C.J. Trade-offs in arbuscular mycorrhizal symbiosis: Disease resistance, growth responses and perspectives for crop breeding. Agronomy 2017, 7, 75. [CrossRef]

16. Sharma, I.P.; Sharma, A.K. Co-inoculation of tomato with an arbuscular mycorrhizal fungus improves plant immunity and reduces root knot nematode infection. Rhizosphere 2017, 4, 25-28. [CrossRef]

17. Sharma, I.P.; Sharma, A.K. Physiological and biochemical changes in tomato cultivar PT-3 with dual inoculation of mycorrhiza and PGPR against root-knot nematode. Symbiosis 2017, 71, 175-183. [CrossRef]

18. Li, F.; Guo, Y.E.; Christensen, M.J.; Gao, P.; Li, Y.; Duan, T. An arbuscular mycorrhizal fungus and Epichloë festucae var. lolii reduce Bipolaris sorokiniana disease incidence and improve perennial ryegrass growth. Mycorrhiza 2018, 28, 159-169. [CrossRef]

19. Balestrini, R.; Rosso, L.C.; Veronico, P.; Melillo, M.T.; De Luca, F.; Fanelli, E.; Colagiero, M.; di Fossalunga, A.S.; Ciancio, A.; Pentimone, I. Transcriptomic responses to water deficit and nematode infection in mycorrhizal tomato roots. Front. Microbiol. 2019, 10, 1807. [CrossRef]

20. Contreras-Cornejo, H.A.; Macías-Rodríguez, L.; Del-Val, E.K.; Larsen, J. Ecological functions of Trichoderma spp. and their secondary metabolites in the rhizosphere: Interactions with plants. FEMS Microbiol. Ecol. 2016, 92, fiw036. [CrossRef]

21. Macías-Rodríguez, L.; Contreras-Cornejo, H.A.; Adame-Garnica, S.G.; Del-Val, E.; Larsen, J. The interactions of Trichoderma at multiple trophic levels: Inter-kingdom communication. Microbiol. Res. 2020, 240, 126552. [CrossRef]

22. Halifu, S.; Deng, X.; Song, X.; Song, R. Effects of two Trichoderma strains on plant growth, rhizosphere soil nutrients, and fungal community of Pinus sylvestris var. mongolica annual seedlings. Forests 2019, 10, 758. [CrossRef]

23. El-Nagdi, W.M.; Youssef, M.M.; Abd El-Khair, H.; Abd-Elgawad, M.M. Effect of certain organic amendments and Trichoderma species on the root-knot nematode, Meloidogyne incognita, infecting pea (Pisum sativum L.) plants. Egypt. J. Biol. Pest Control 2019, 29, 1-9. [CrossRef]

24. Hussey, R.S.; Barker, K.R. A comparison of methods of collecting inocula of Meloidogyne spp., including a new technique. Plant Dis. Rep. 1973, 61, 328-331.

25. Cesarz, S.; Schulz, A.E.; Beugnon, R.; Eisenhauer, N. Testing soil nematode extraction efficiency using different variations of the Baermann-funnel method. Soil Org. 2019, 91, 61.

26. Gerdemann, J.W.; Nicolson, T.H. Spores of mycorrhizal Endogone species extracted from soil by wet sieving and decanting. Trans. Brit. Mycol. Soc. 1963, 46, 235-244. [CrossRef]

27. Redecker, D.; Schüßler, A.; Stockinger, H.; Stürmer, S.L.; Morton, J.B.; Walker, C. An evidence-based consensus for the classification of arbuscular mycorrhizal fungi (Glomeromycota). Mycorrhiza 2013, 23, 515-531. [CrossRef] [PubMed]

28. Glickmann, E.; Dessaux, Y. A critical examination of the specificity of the Salkowski reagent for indolic compounds produced by phytopathogenic bacteria. Appl. Environ. Microbiol. 1995, 61, 793-796. [CrossRef]

29. Hassan, E.A.; Mostafa, Y.S.; Alamri, S.; Hashem, M.; Nafady, N.A. Biosafe Management of Botrytis Grey Mold of Strawberry Fruit by Novel Bioagents. Plants 2021, 10, 2737. [CrossRef]

30. Yin, D.C.; Deng, X.; Chet, I. Inhibiting effect and mechanism of Trichoderma virens T43 on four major species of forest pathogen. Chin. J. Ecol. 2014, 33, 1911-1919.

31. Jackson, M.L. Soil Chemical Analysis: Advanced Course; UW-Madison Libraries Parallel Press: Madison, WI, USA, 2005.

32. Lichtenthaler, H.K. Chlorophylls and carotenoids: Pigments of photosynthetic biomembranes. Meth. Enzymol. 1987, 148, 350-382.

33. Sellers, R.M. Spectrophotometric determination of hydrogen peroxide using potassium titanium (IV) oxalate. Analyst 1980, 105, 950-954. [CrossRef]

34. Hodges, D.M.; DeLong, J.M.; Forney, C.F.; Prange, R.K. Improving the thiobarbituric acid-reactive-substances assay for estimating lipid peroxidation in plant tissues containing anthocyanin and other interfering compounds. Planta 1999, 207, 604-611. [CrossRef]

35. Aebi, H. Catalase in vitro. Methods Enzym. 1984, 105, 121-126.

36. Tatiana, Z.; Yamashita, K.; Matsumoto, H. Iron deficiency induced changes in ascorbate content and enzyme activities related to ascorbate metabolism in cucumber roots. Plant Cell Physiol. 1999, 40, 273-280.

37. Lowry, O.H.; Rosebrough, N.J.; Farr, A.L.; Randall, R.J. Protein measurement with the folin phenol reagent. J. Biol. Chem. 1951, 193, 265-275. [CrossRef]

38. Sampietro, D.A.; Sgariglia, M.A.; Soberón, J.R.; Quiroga, E.N.; Vattuone, M.A. Colorimetric reactions. In Isolation, Identification and Characterization of Allelochemicals/Natural Products; Sampietro, D.A., Catalan, C.A., Vattuone, M.A., Narwal, S.S., Eds.; Science Publishers: Enfield, NH, USA, 2009; pp. 73-101.

39. Dence, C.W. The determination of lignin. In Methods in Lignin Chemistry; Lin, S.Y., Dence, C.W., Eds.; Springer: Berlin/Heidelberg, Germany, 1992; pp. 33-61.

40. Phillips, J.M.; Hayman, D.S. Improved procedures for clearing roots and staining parasitic and vesicular-arbuscular mycorrhizal fungi for rapid assessment of infection. Trans. Brit. Mycol. Soc. 1970, 55, 158-IN18. [CrossRef] 
41. Kumar, A.; Verma, J.P. Does plant-microbe interaction confer stress tolerance in plants: A review? Microb. Res. 2018, 207, 41-52. [CrossRef]

42. Ji, X.; Li, J.; Dong, B.; Zhang, H.; Zhang, S.; Qiao, K. Evaluation of fluopyram for southern root-knot nematode management in tomato production in China. Crop Prot. 2019, 122, 84-89. [CrossRef]

43. Yan, Y.; Mao, Q.; Wang, Y.; Zhao, J.; Fu, Y.; Yang, Z.; Peng, X.; Zhang, M.; Bai, B.; Liu, A.; et al. Trichoderma harzianum induces resistance to root-knot nematodes by increasing secondary metabolite synthesis and defense-related enzyme activity in Solanum lycopersicum L. Biol. Control 2021, 158, 104609. [CrossRef]

44. Nieto-Jacobo, M.F.; Steyaert, J.M.; Salazar-Badillo, F.B.; Nguyen, D.V.; Rostás, M.; Braithwaite, M.; De Souza, J.T.; Jimenez-Bremont, J.F.; Ohkura, M.; Stewart, A.; et al. Environmental growth conditions of Trichoderma spp. affects indole acetic acid derivatives, volatile organic compounds, and plant growth promotion. Front. Plant Sci. 2017, 8, 102. [CrossRef]

45. Bharucha, U.; Patel, K.; Trivedi, U.B. Optimization of indole acetic acid production by Pseudomonas putida UB1 and its effect as plant growth-promoting rhizobacteria on mustard (Brassica nigra). Agric. Res. 2013, 2, 215-221. [CrossRef]

46. Contreras-Cornejo, H.A.; Macías-Rodríguez, L.; del-Val, E.; Larsen, J. Interactions of Trichoderma with plants, insects, and plant pathogen microorganisms: Chemical and molecular bases. In Co-Evolution of Secondary Metabolites; Mérillon, J.M., Ramawat, K., Eds.; Springer International Publishing: Cham, Switzerland, 2020; pp. 263-290.

47. Nafady, N.A.; Hassan, E.A.; Abd-Alla, M.H.; Bagy, M.M.K. Effectiveness of eco-friendly arbuscular mycorrhizal fungi biofertilizer and bacterial feather hydrolysate in promoting growth of Vicia faba in sandy soil. Biocatal. Agric. Biotechnol. 2018, 16, 140-147. [CrossRef]

48. TariqJaveed, M.; Farooq, T.; Al-Hazmi, A.S.; Hussain, M.D.; Rehman, A.U. Role of Trichoderma as a biocontrol agent (BCA) of phytoparasitic nematodes and plant growth inducer. J. Invertebr. Pathol. 2021, 183, 107626. [CrossRef] [PubMed]

49. Liu, R.; Dai, M.; Wu, X.; Li, M.; Liu, X. Suppression of the root-knot nematode [Meloidogyne incognita (Kofoid \& White) Chitwood] on tomato by dual inoculation with arbuscular mycorrhizal fungi and plant growth-promoting rhizobacteria. Mycorrhiza 2012, 22, 289-296.

50. Detrey, J.; Cognard, V.; Djian-Caporalino, C.; Marteu, N.; Doidy, J.; Pourtau, N.; Vriet, C.; Maurousset, L.; Bouchon, D.; Clause, J. Growth and root-knot nematode infection of tomato are influenced by mycorrhizal fungi and earthworms in an intercropping cultivation system with leeks. Appl. Soil Ecol. 2022, 169, 104181. [CrossRef]

51. Marro, N.; Caccia, M.; Doucet, M.E.; Cabello, M.; Becerra, A.; Lax, P. Mycorrhizas reduce tomato root penetration by false root-knot nematode Nacobbus aberrans. Appl. Soil Ecol. 2018, 124, 262-265. [CrossRef]

52. Stoffelen, R.; Verlinden, R.; Xuyen, N.T.; Swennen, R.; De Waele, D. Host plant response of Eumusa and Australimusa bananas (Musa spp.) to migratory endoparasitic and root-knot nematodes. Nematology 2000, 2, 907-916.

53. Khanna, K.; Jamwal, V.L.; Sharma, A.; Gandhi, S.G.; Ohri, P.; Bhardwaj, R.; Al-Huqail, A.A.; Siddiqui, M.H.; Marraiki, N.; Ahmad, P. Evaluation of the role of rhizobacteria in controlling root-knot nematode infection in Lycopersicon esculentum plants by modulation in the secondary metabolite profiles. AoB Plants 2019, 11, plz069. [CrossRef]

54. Vasil'Eva, I.; Vanyushkin, S.; Zinov'Eva, S.; Udalova, Z.V.; Bolychevtseva, Y.V.; Paseshnichenko, V. Photosynthetic pigments of tomato plants under conditions of biotic stress and effects of furostanol glycosides. Appl. Biochem. Microbiol. 2003, 39, 606-612. [CrossRef]

55. Mohammadi, M.A.; Cheng, Y.; Aslam, M.; Jakada, B.H.; Wai, M.H.; Ye, K.; He, X.; Luo, T.; Ye, L.; Dong, C.; et al. ROS and Oxidative Response Systems in Plants Under Biotic and Abiotic Stresses: Revisiting the Crucial Role of Phosphite Triggered Plants Defense Response. Front. Microbiol. 2021, 12, 631318. [CrossRef]

56. Wuyts, N.; Lognay, G.; Swennen, R.; De Waele, D. Nematode infection and reproduction in transgenic and mutant Arabidopsis and tobacco with an altered phenylpropanoid metabolism. J. Experim. Bot. 2006, 57, 2825-2835. [CrossRef]

57. Wyss, U. Feeding behaviour of plant-parasitic nematodes. In The Biology of Nematodes; Lee, D.L., Ed.; Taylor and Francis: London, UK, 2002; pp. 233-259.

58. Sahebani, N.; Hadavi, N. Biological control of the root-knot nematode Meloidogyne javanica by Trichoderma harzianum. Soil Biol. Biochem. 2008, 40, 2016-2020. [CrossRef]

59. Bokhari, F.M. Efficacy of some Trichoderma species in the control of Rotylenchulus reniformis and Meloidogyne javanica. Arch. Phytopathol. Plant Prot. 2009, 42, 361-369. [CrossRef]

60. Sharma, I.P.; Sharma, A.K. Mycorrhizal colonization and phosphorus uptake in presence of PGPRs along with nematode infection. Symbiosis 2019, 77, 185-187. [CrossRef] 